\title{
Microbiological Studies during the Different Treatments of Drinking Water in Road EI- Farag Station
}

\author{
Marwa M. Taha' ${ }^{1}$; Nassem A. Neweigy ${ }^{1}$; Talaat M. El-Husseiny ${ }^{1}$; Hussein E Makboul ${ }^{2}$ and Ahmed A. Salem ${ }^{1}$ \\ 1- Agric. Microbiology Dept., Fac. Agric. Moshtohor, Benha Univ., Egypt \\ 2- Agric. Microbiology Dept., Fac. Agric., Cairo Univ., Egypt \\ Corresponding Author: Ahmed_nayl1978@yahoo.com
}

\begin{abstract}
The collected water samples were microbiologically evaluated, the total bacterial count was evaluated at $22^{\circ} \mathrm{C}$ and $37^{\circ} \mathrm{C}$. Total bacterial counts at different seasons of investigations revealed that $37^{\circ} \mathrm{C}$ obtained higher rate of bacterial counts than at $22^{\circ} \mathrm{C}$. Total coliform was also recorded for water samples that obtained directly from the River Nile during all examination periods. There was no E. coli contamination found in the final treatment stage and all distribution regions. No fecal streptococci contamination was found in the final treatment stage and all distribution regions. The highest Salmonella and Shigella counts were recorded for water samples obtained directly from the River Nile during all examination seasons. On the other hand, Salmonella and Shigella were not detected in all distribution regions. Higher value of turbidity was observed during the summer period followed by the spring in both seasons. During the investigation period $\mathrm{pH}$ values ranged between 7.0 to 8.4. The highest $\mathrm{pH}$ value was recorded during winter 2017 . Whereas, the lowest value was recorded during autumn 2016. The lowest COD values were recorded in summer 2016 and winter 2017. Whereas, the highest COD values were recorded in summer 2017 for water samples that obtained directly from the River Nile during all examination seasons. The highest BOD value $(15.2 \mathrm{mg} / \mathrm{l})$ was recorded in winter 2017 for water samples that obtained directly from the River Nile during all examination seasons.
\end{abstract}

Keywords: Microbiological studies, Drinking water, Road El-Farag station, fecal streptococci, E. coli and Salmonella sp.

\section{Introduction}

Water is fundamental to maintain life, because all organisms are made up mostly by water. Water in general obtained from two natural sources, include surface water such as seas, lakes and rivers (Annual Drinking Water Quality Report, 2005). Contaminated water causes problems to health and leads to waterborne diseases which can be prevented by taking measures even at the household level. Providing safe water for human uses is a challenging task. Continued research efforts in this area for more than few decades resulted in many processes/technologies (Shannon et al., 2008).

The microbial contaminants include pathogens like bacteria, viruses and parasites such as microscopic protozoa and worms. These living organisms can be spread by human and animal waste knowing or unknowingly some contaminants can be easily identified by assessing color, odor, turbidity and the taste of the water. However, most contaminants cannot be easily detected and require different test to reveal whether water is contaminated or not. Thus, the contaminants may result in unappealing taste or odor and stay as well as health effects (Sharma and Bhattacharya 2017).

Rivers are the most important fresh water resources and the River Nile has played an extremely important role in the civilization, life and history of the Egyptian Nation (Dimian et al., 2014). River Nile is the longest river in the world, located in the north-east of the continent of Africa, and stems specifically from Lake Victoria and ends in the Mediterranean Sea, with a length of 6695 kilometers. The Nile basin covers more than three million kilometers and it passes through 11 countries. The upstream States are Uganda, Ethiopia, Eritrea, Congo, Burundi, Tanzania, Rwanda, Kenya and the down-stream states, South of Sudan, Sudan and Egypt (Encyclopedia Britannica, 2017).

The present work focused the microbiological and chemical evaluation during the different treatments of drinking water in Road EL-Farag station during 2016 and 2017 seasons. The evaluation was based on the seasonal variation correlations between the microbiological and physicochemical parameters. The spatial and temporal pattern of bacteriological contamination (total count, total coliform, faecal streptococci, $E$. coli and Salmonella \& Shigella) were investigated.

Moreover, water turbidity, temperature, $\mathrm{pH}$, biological oxygen demand and chemical oxygen demand content were also examined.

\section{Materials and Methods}

\section{Materials}

\section{Source of sample}

This study was carried out on Road El-Farag station, great Cairo, Egypt. Samples were collected during different stages (Nile River, clarification, 
filtration and the distribution system) during two different seasons $(2016$ - 2017). Samples from the distribution system were withdrawn from Road ElFarag station, El-Azhar and El-Abasia region respectively.

\section{Sampling}

Samples were collected in spring, summer, autumn and winter during two seasons 2016 - 2017 in accordance to the standard method for the examination of water and wastewater (APHA, 2005). Samples were collected in sterilized bottle $(250 \mathrm{ml})$ and transported in ice box. Samples were preserved under cooling condition at $5^{\circ} \mathrm{C}$ and the microbiological examinations were conducted during $18 \mathrm{hr}$. from sampling. Samples which representative the chlorinated drinking water were contain $1 \mathrm{ml}$ thiosulphate solution (10\%) for each $120 \mathrm{ml}$ of the sample

\section{Media used}

The following media were used throughout this study: Tryptone Glucose Yeast Agar (APHA, 1999), this medium was used for determining total microbial count at $22^{\circ} \mathrm{C}$ and $37^{\circ} \mathrm{C}$. Azide dextrose broth medium (APHA, 1999), used for determining faecal streptococci by MPN technique. Mac-Conkey Broth medium (APHA, 2005), used for counting coliform bacteria using MPN technique. Eosin Methylene Blue (EMP) agar medium (APHA, 1999), used for confirmatory test of coliform as well as counting of Salmonella \& Shigella agar (APHA, 1999).

\section{Methods}

Microbiological examination

All water samples used in the present investigation were subjected to bacteriological evaluation and total microbial count at two different temperatures $\left(22^{\circ} \mathrm{C}\right.$ and $\left.37^{\circ} \mathrm{C}\right)$, coliform group $\{$ Total coliform (TC), faecal streptococci (FS)\}, E. coli, Salmonella sp., Shigella were carried out according to standard method of (APHA, 2005).

\section{Physical and chemical examination}

Physicochemical analyses were performed according to the standard methods for examination of water and wastewater suggested by American Public Health Association (APHA, 2005). Temperature $\left({ }^{\circ} \mathrm{C}\right)$ was estimated using thermal thermometer. $\mathrm{pH}$ values were determined using portable $\mathrm{pH}$ meter with electrode (WTW Model pH 197). Turbidity values were determined using HACH- RATIO/XRturbidimeter gelex secondary turbidity standards (1800, 180, 18, 1.8 NTU). Chemical oxygen demand COD and BOD were measured gravimetrically according to Stirling(1985).

\section{Results and Discussion}

\section{Microbiological analyses Total bacterial count}

Water is essential to sustain life and a satisfactory supply must be provided to consumers. An enormous effort should be made to achieve a drinking water quality as high as practicable. Failure to provide adequate protection and effective treatment of drinking water will expose the community to the risk of outbreaks of intestinal and other infectious diseases (WHO, 1996). The collected water samples were microbiologically evaluated and the total bacterial counts were detected at $22^{\circ} \mathrm{C}$ and $37^{\circ} \mathrm{C}$. The obtained data were presented in Tables (1 and 2)

Table 1. Seasonally changes in total bacterial count at $22^{\circ} \mathrm{C}$ in various treatment stages in Road El. Farag drinking water station.

\begin{tabular}{|c|c|c|c|c|c|c|c|c|}
\hline \multirow{3}{*}{ Locations } & \multicolumn{8}{|c|}{ Total counts at $22^{\circ} \mathrm{C}(\log \mathrm{CFU} / \mathrm{ml})$} \\
\hline & \multicolumn{4}{|c|}{2016} & \multicolumn{4}{|c|}{2017} \\
\hline & Spring & Summer & Autumn & Winter & Spring & Summer & Autumn & Winter \\
\hline The source (River Nile) & 2.75 & 3.54 & 2.69 & 2.72 & 3.80 & 3.93 & 3.81 & 2.72 \\
\hline Clarification stage & $\mathrm{ND}^{*}$ & 0.24 & 0.13 & ND & 0.16 & 0.31 & ND & ND \\
\hline Filtration stage & ND & 0.22 & ND & ND & ND & 0.18 & 0.13 & ND \\
\hline Final treatment & ND & ND & ND & ND & ND & ND & ND & ND \\
\hline \multicolumn{9}{|l|}{ Distribution regions } \\
\hline Road El-Farag & 0.4 & 0.7 & 0.5 & ND & 0.4 & 0.2 & ND & 0.1 \\
\hline El-Azhar & ND & 0.5 & 0.6 & ND & 0.7 & 0.3 & 0.5 & ND \\
\hline El-Abasia & ND & 0.7 & ND & 0.5 & ND & 0.6 & $\mathrm{ND}$ & 0.7 \\
\hline
\end{tabular}

${ }^{*} \mathrm{ND}=$ not detected

The highest bacterial counts were recorded for water samples that obtained directly from the River Nile during all examination periods. Incubation of samples at $37^{\circ} \mathrm{C}$ resulted in high appearance rate of bacterial counts than incubation at $22^{\circ} \mathrm{C}$. Appearance of bacteria in the distribution system indicating high pollution rate that can be explained as over $90 \%$ of
Cairo's drinking water is drawn from the Nile. The Cairo Water Authority has 16 clean water treatment plants. The finished water goes to storage or pump stations for distribution and at this point, microbial contamination enters the distribution system (ElGohary, 1994)

Moreover, problems in the water distribution 
system or storage sometimes lead to erratic water supplies and/or contaminants entering the drinking water in several areas (Saleh $\boldsymbol{e t}$. $\boldsymbol{a l}$., 2001). Time and temperature of incubation are very significant variables, high temperature incubation $\left(35-37^{\circ} \mathrm{C}\right)$ and short incubation time (34-48h) favor the growth of bacteria from animals and human, Low temperature incubation $\left(20-28^{\circ} \mathrm{C}\right)$ and longer incubation time (5-7days) favour the growth of water-based bacteria (Allen et. al., 2004).

Table 2. Seasonally changes in total bacterial count at $37^{\circ} \mathrm{C}$ in various treatment stages in Road El. Farag drinking water station.

\begin{tabular}{|c|c|c|c|c|c|c|c|c|}
\hline \multirow[t]{3}{*}{ Locations } & \multicolumn{8}{|c|}{ Total counts at $37^{\circ} \mathrm{C}(\log \mathrm{CFU} / \mathrm{ml})$} \\
\hline & \multicolumn{4}{|c|}{2016} & \multicolumn{4}{|c|}{2017} \\
\hline & Spring & Summer & Autumn & Winter & Spring & Summer & Autumn & Winter \\
\hline The source (River Nile) & 3.88 & 4.97 & 3.79 & 3.76 & 4.94 & 5.18 & 4.96 & 3.98 \\
\hline Clarification stage & ND & 0.5 & 0.5 & ND & 0.6 & 0.9 & ND & 0.3 \\
\hline Filtration stage & 0.6 & 0.5 & ND & ND & 0.3 & 0.4 & ND & ND \\
\hline Final treatment & ND & ND & ND & ND & ND & ND & ND & ND \\
\hline \multicolumn{9}{|l|}{ Distribution regions } \\
\hline Road El-Farag & ND & 0.1 & 0.2 & ND & 0.1 & 0.3 & 0.2 & 0.1 \\
\hline El-Azhar & ND & 0.1 & ND & 0.1 & ND & 0.1 & ND & 0.2 \\
\hline El-Abasia & 0.2 & ND & 0.2 & ND & ND & 0.3 & 0.2 & ND \\
\hline
\end{tabular}

In both tables $(1 \& 2)$, total bacterial count ranged between 2.7 to $3.8 \mathrm{cfu} / 100 \mathrm{ml}$ at $22^{\circ} \mathrm{C}$ and 3.8 to 4.9 cfu/100 ml respectively at the entrance of Rod ELFarag station (River Nile resource). Such counts were strongly declined or not detected during the different treatments. Osman et. al., (2011) found that the highest average log count of Nile water at $37^{\circ} \mathrm{C}$ reached $6.4 \mathrm{cfu} / 100 \mathrm{~mL}$ in EL-Giza district, followed by Helwan, Shubbra EL-Khema and lastly Embaba being 5.8, 5.63 and $6.4 \mathrm{cfu} / 100 \mathrm{~mL}$, respectively. On other hand, the highest average log count of Nile water at $22^{\circ} \mathrm{C}$ reached $6.2 \mathrm{cfu} / 100 \mathrm{~mL}$ in both Helwan and EL-Giza region, while Shubbra ELKhema and Embaba region recorded lower count, being 5.42 and $2.9 \mathrm{cfu} / 100 \mathrm{~mL}$, respectively. ELTaweel and Shaban, (2003) reported that the log total bacterial count of Nile water ranged from 4.1 to $7.4 \mathrm{cfu} / 100 \mathrm{~mL}$ at $22^{\circ} \mathrm{C}$, while it reached from 4.1 to $7.3 \mathrm{cfu} / 100 \mathrm{~mL}$ at $37^{\circ} \mathrm{C}$.

\section{Total coliform (TC) count}

The coliform group is probably the earliest water pollution indicator to detect faecal pollution and prevalence of pathogenic bacteria in water and wastewater (APHA, 2005). Coliform group includes multiple bacterial genera such as Escherichia, Klebsiella, Enterobacter and Citrobacter. Data presented in Table (3) clearly indicated that, the highest total coliform counts were recorded for water samples that obtained directly from the River Nile during all examination periods.

Table 3. Seasonally changes in total coliform (TC) in various treatment stages in Road El. Farag drinking water station.

\begin{tabular}{|c|c|c|c|c|c|c|c|c|}
\hline \multirow{3}{*}{ Locations } & \multicolumn{8}{|c|}{ Total coliform $(\log \mathrm{CFU} / \mathrm{ml})$} \\
\hline & \multicolumn{4}{|c|}{2016} & \multicolumn{4}{|c|}{2017} \\
\hline & Spring & Summer & Autumn & Winter & Spring & Summer & Autumn & Winter \\
\hline The source (River Nile) & 2.10 & 2.54 & 2.14 & 2.14 & 2.23 & 2.38 & 2.04 & 2.27 \\
\hline Clarification stage & ND & 0.13 & ND & ND & 0.6 & 0.5 & ND & ND \\
\hline Filtration stage & 0.5 & 0.4 & ND & ND & 0.4 & 0.3 & 0.6 & 0.4 \\
\hline Final treatment & ND & ND & ND & ND & ND & ND & ND & ND \\
\hline \multicolumn{9}{|l|}{ Distribution regions } \\
\hline Road El-Farag & ND & ND & ND & ND & ND & ND & ND & ND \\
\hline El-Azhar & ND & ND & ND & ND & ND & 0.1 & ND & ND \\
\hline El-Abasia & ND & ND & ND & ND & 0.2 & ND & ND & ND \\
\hline
\end{tabular}

In this respect total coliform was absolutely absent near Rod EL Farag station (ND). But in some cases of summer $2017 \quad(0.1 \mathrm{cfu} / 100 \mathrm{ml})$ was appeared, in EL-Azher region or $0.2 \mathrm{cfu} / 100 \mathrm{ml}$ in EL-Abasia region. Such TC counts could be indicated as a pollution for water system from the walls of the old pipes which provide ideal surface for microbial colonization and biofilm formed causing a number of problems for the water companies (Charmain et al., 2003). In addition, despite effective treatment of drinking water, microbes can enter water utility distribution system and biofilm 
formation may account for the persistence of microbes in the distribution system (MarcianoCabral, 2010). Additionally, microorganism can also enter distribution network during installation, repair or replacement of infrastructure and by net ingress under dynamic or another depressurization event (Besner et al., 2011).

Also, obtained data indicated high coliform counts in summer than the other seasons which can be attributed to the high atmospheric temperature. The obtained results are in harmony with Silva et al., (2008) they found that, microbiological characteristics of tap water was as following: heterotrophic plate count $500 \mathrm{CPU}$, total coliforms 0 , fecal coliforms 0, E. coli 0, Staphylococcus spp. 0, Pseudomonas aeruginosa 0 , fecal streptococci 0 and no sulfite-reducing clostridia were detected.

\section{E. Coli count}

E.coli strains are a natural and essential part of the bacterial flora in the gut of humans and animals. Most E. coli strains are non-pathogenic and reside harmless in the colon. However, certain serotypes play a role in intestinal and extra-intestinal diseases such as urinary tract infections (Gordon and FitzGibbon, 1999). Currently, coliforms and E. coli are of great importance among bacterial indicators used in water quality definition and health risk (Giannoulis et al., 2005). The results presented in Table (4) clearly show high pollution rate with $E$. coli in the River Nile as well as clarification and filtration stages.

Table 4. Seasonally changes in E. coli count in various treatment stages in Road El. Farag drinking water station.

\begin{tabular}{|c|c|c|c|c|c|c|c|c|}
\hline \multirow[t]{3}{*}{ Locations } & \multicolumn{8}{|c|}{ E. coli count $(\log$ CFU/ml) } \\
\hline & \multicolumn{4}{|c|}{2016} & \multicolumn{4}{|c|}{2017} \\
\hline & Spring & Summer & Autumn & Winter & Spring & Summer & Autumn & Winter \\
\hline The source (River Nile) & 1.73 & 2.74 & 1.30 & 2.10 & 2.23 & 2.50 & 2.11 & 2.14 \\
\hline Clarification stage & ND & 0.3 & ND & ND & 0.2 & 0.4 & ND & ND \\
\hline Filtration stage & 0.1 & 0.3 & 0.4 & ND & ND & 0.3 & ND & ND \\
\hline Final treatment & ND & ND & ND & ND & ND & ND & ND & ND \\
\hline Distribution regions & & & & & & & & \\
\hline Road El-Farag & ND & ND & ND & ND & ND & ND & ND & ND \\
\hline El-Azhar & ND & ND & ND & ND & ND & ND & ND & ND \\
\hline El-Abasia & ND & ND & ND & ND & ND & ND & ND & ND \\
\hline
\end{tabular}

${ }^{*} \mathrm{ND}=$ not detected

Obtained data also indicated high $E$. coli count in the supplier source (River Nile) in summer than the other seasons which can be attributed to the high atmospheric temperature. Moreover, there were no $E$. coli contamination found in the distribution system (Road EL-Farag, EL-Azhar and EL-Abasia).

\section{Fecal streptococci count}

The use of indicator bacteria such as faecal streptococci for assessment of faecal pollution and possible water quality deterioration in fresh water sources is widely used (Sabae and Rabeh, 2007). The faecal streptococcus group consists of a number of species of the genus Streptococcus, such as $S$. faecalis, S. faceium, S.bovis, S. equines, S. avium and $S$. gallinarum that are normally found in faeces and gut of warm-blooded animals. Unlike the coliform bacteria, they are Gram-positive and also tend to live longer in water than faecal coliforms (Manafi, 1999).

Table 5. Seasonally changes in faecal streptococci (FC) count in various treatment stages in Road El. Farag drinking water station.

\begin{tabular}{|c|c|c|c|c|c|c|c|c|}
\hline \multirow{3}{*}{ Locations } & \multicolumn{8}{|c|}{ Fecal Streptococci count (log CFU/ml) } \\
\hline & \multicolumn{4}{|c|}{2016} & \multicolumn{4}{|c|}{2017} \\
\hline & Spring & Summer & Autumn & Winter & Spring & Summer & Autumn & Winter \\
\hline The source (River Nile) & 0.76 & 1.10 & 0.2 & 0.4 & ND & 0.3 & 0.2 & 0.3 \\
\hline Clarification stage & ND & 0.02 & ND & ND & ND & ND & ND & ND \\
\hline Filtration stage & ND & ND & ND & ND & ND & ND & ND & ND \\
\hline Final treatment & ND & ND & ND & ND & ND & ND & ND & ND \\
\hline \multicolumn{9}{|l|}{ Distribution regions } \\
\hline Road El-Farag & ND & ND & ND & ND & ND & ND & ND & ND \\
\hline El-Azhar & ND & ND & ND & ND & ND & ND & ND & ND \\
\hline El-Abasia & ND & ND & ND & ND & ND & ND & ND & ND \\
\hline
\end{tabular}

$\mathrm{ND}=$ not detected

Data presented in Table (5) indicated that no fecal streptococci contamination was found in the filtration stage, final treatment stage and all the distribution regions. Fecal streptococci counts were recorded for water samples that obtained directly from the River Nile during all examination periods. 
Obtained data also indicated high faecal counts of streptococci in summer than the other seasons. This finding agrees with Ezzat et al. (2012) who found that faecal streptococci counts in the river Nile (Rosetta branch) ranged between $(8-11) * 10^{4} \mathrm{CFU} / 100 \mathrm{ml}$. Also, Abo-State et al. (2014) revealed that $99 \%$ of 116 faecal streptococci samples collected from 11 locations at the river Nile ranged between $\left(1.0 * 10^{1}\right.$ $\left.7.0 * 10^{4} \mathrm{CFU} / \mathrm{ml}\right)$ during the year seasons of their study.

\section{Salmonella and Shigella count}

Data presented in Table (6) clearly show that the highest Salmonella and Shigella counts were recorded for water samples that obtained directly from the River Nile during all examination seasons. Moreover, Salmonella and Shigella were not detected in all distribution regions and the final treatment stage.

Table 6. Seasonally changes in Salmonella and Shigella count in various treatment stages in Road El. Farag drinking water station.

\begin{tabular}{|c|c|c|c|c|c|c|c|c|}
\hline \multirow{3}{*}{ Locations } & \multicolumn{8}{|c|}{ Salmonella and Shigella count (log CFU/ml) } \\
\hline & \multicolumn{4}{|c|}{2016} & \multicolumn{4}{|c|}{2017} \\
\hline & Spring & Summer & Autumn & Winter & Spring & Summer & Autumn & Winter \\
\hline The source (River Nile) & 0.4 & 0.6 & 0.2 & 0.1 & 0.2 & 0.3 & 0.2 & 0.3 \\
\hline Clarification stage & ND & 0.2 & ND & ND & ND & 0.1 & ND & ND \\
\hline Filtration stage & 0.12 & ND & ND & ND & ND & ND & 0.2 & ND \\
\hline Final treatment & ND & ND & ND & ND & ND & ND & ND & ND \\
\hline \multicolumn{9}{|l|}{ Distribution regions } \\
\hline Road El-Farag & ND & ND & ND & ND & ND & ND & ND & ND \\
\hline El-Azhar & ND & ND & ND & ND & ND & ND & ND & ND \\
\hline El-Abasia & ND & ND & ND & ND & ND & ND & ND & ND \\
\hline
\end{tabular}

The obtained results are in accordance with Ali $\boldsymbol{e t}$ al. (2015), in which they reported that pathogenic bacteria (Salmonella sp., Shigella sp. and E. coli) were detected in water samples of both sites in River Nile; after and before El-Sail drain with higher values in site II than site I.

\section{Physicochemical analyses Determination of water turbidity}

Turbidity is now seen as a key for water pollution, but it also often used as a surrogate variable for suspended solids concentration. Indeed, in most cases; suspended solids are regarded as the primary indicator of pollution (Akan and Houghtalen, 2003). Turbidity is the measure of fine suspended matter in water, mostly caused by colloidal particles such as clay, silt, living and nonliving organisms.

In this respect, results in Table (7) clearly indicated that the highest value of turbidity was observed during summer followed by the spring in both seasons. Whereas, the lowest value was recorded in autumn for water samples that obtained directly from the River Nile during all examination seasons.

Table 7. Seasonally changes in turbidity (NTU) in various treatment stages in Road El. Farag drinking water station.

\begin{tabular}{|c|c|c|c|c|c|c|c|c|}
\hline \multirow{3}{*}{ Locations } & \multicolumn{8}{|c|}{ Turbidity (NTU) } \\
\hline & \multicolumn{4}{|c|}{2016} & \multicolumn{4}{|c|}{2017} \\
\hline & Spring & Summer & Autumn & Winter & Spring & Summer & Autumn & Winter \\
\hline The source (River Nile) & 11.8 & 12.3 & 9.3 & 11.7 & 11.5 & 13.2 & 9.0 & 10.5 \\
\hline Clarification stage & 0.22 & 0.31 & 0.42 & 0.25 & 0.54 & 0.65 & 0.72 & 0.25 \\
\hline Filtration stage & 0.48 & 0.41 & 0.41 & 0.42 & 0.44 & 0.40 & 0.44 & 0.38 \\
\hline Final treatment & 0.46 & 0.37 & 0.45 & 0.44 & 0.42 & 0.42 & 0.44 & 0.48 \\
\hline \multicolumn{9}{|l|}{ Distribution regions } \\
\hline Road El-Farag & 0.00 & 0.00 & 0.00 & 0.00 & 0.00 & 0.00 & 0.00 & 0.00 \\
\hline El-Azhar & 0.00 & 0.00 & 0.00 & 0.00 & 0.00 & 0.00 & 0.00 & 0.00 \\
\hline El-Abasia & 0.00 & 0.00 & 0.00 & 0.00 & 0.00 & 0.00 & 0.00 & 0.00 \\
\hline
\end{tabular}

Moreover, no turbidity was recorded during the all examined distribution system. These results were reversible to results obtained by Abdel-Satar et al . (2017) who reported that transparency values were lower (turbidity was higher) during winter.

\section{Determination of water temperature}

The changes of water temperature may depend on the variations in meteorological conditions, air temperature, latent heat of evaporation and different sampling times and seasons (Abdel-Satar, 2005; 
Mahmoud et al., 2008; Saad et al., 2011 and Ahmed, 2012).

Seasonally changing in water temperature were recorded in Table (8). Values were ranged between $17.0-32.1^{\circ} \mathrm{C}$ and the highest temperature $\left(32.1^{\circ} \mathrm{C}\right)$ was recorded during summer 2016. Moreover, lower temperatures were recorded during winter followed by spring in all locations.

Table 8. Seasonally changes in temperature $\left({ }^{\circ} \mathrm{C}\right)$ in various treatment stages in Road El. Farag drinking water station.

\begin{tabular}{l|cccccccc}
\hline \multirow{2}{*}{ Locations } & \multicolumn{8}{c}{ Temperature ( C) } \\
\cline { 2 - 9 } & \multicolumn{7}{c}{$\mathbf{2 0 1 6}$} & \multicolumn{7}{c}{$\mathbf{2 0 1 7}$} \\
\cline { 2 - 9 } & Spring & Summer & Autumn & Winter & Spring & Summer & Autumn & Winter \\
\hline The source (River Nile) & 20.0 & 26.8 & 19.0 & 17.0 & 22.5 & 26.8 & 19.0 & 18.0 \\
Clarification stage & 21.3 & 29.3 & 21.3 & 19.2 & 23.2 & 25.4 & 19.5 & 19.6 \\
Filtration stage & 22.5 & 32.1 & 22.3 & 18.5 & 24.5 & 28.4 & 27.4 & 21.9 \\
Final treatment & 25.0 & 27.5 & 20.1 & 17.8 & 24.6 & 27.8 & 22.8 & 22.4 \\
Distribution regions & & & & & & & & \\
$\quad \quad$ Road El-Farag & 17.5 & 23.1 & 22.4 & 21.3 & 18.4 & 29.3 & 21.3 & 22.5 \\
$\quad$ El-Azhar & 19.4 & 29.5 & 19.4 & 29.4 & 23.6 & 29.4 & 22.6 & 21.3 \\
$\quad$ El-Abasia & 22.6 & 24.1 & 18.3 & 19.4 & 21.2 & 27.2 & 19.4 & 22.3 \\
\hline
\end{tabular}

These results were in harmony with El- Gammal and El-Shazely (2008) who recorded that the temperature along Rosetta branch ranged from 20 to $30^{\circ} \mathrm{C}$ at various seasons. In addition, Ezzat et al. (2012) reported that temperature changes ranged from $25.5^{\circ} \mathrm{C}$ to $27.7^{\circ} \mathrm{C}$ in drains outlets and between $25^{\circ} \mathrm{C}$ to $28.3^{\circ} \mathrm{C}$ along Rosetta branch sites during summer 2010 and winter 2011. Moreover, temperature change depends mainly on the climatic conditions. Similarly, results by Abdel-Satar et al. (2017) showed that temperature ranged between 17.8 to $18.9^{\circ} \mathrm{C}$ during winter and between 18.7 to $27.9^{\circ} \mathrm{C}$ during spring. While, during summer and autumn the temperature ranged between 24.5 to $30.7^{\circ} \mathrm{C}$ and 20.5 to $26.8^{\circ} \mathrm{C}$, respectively.

Determination of the $\mathbf{p H}$

Regarding the seasonally changes of $\mathrm{pH}$ data presented in Table (9) indicated that $\mathrm{pH}$ values ranged between 7.0 to 8.4 . The highest value was recorded during winter 2017. Whereas, the lowest value was recorded during autumn 2016. In this respect, El-Gammal and El-Shazely (2008) reported that $\mathrm{pH}$ values of 24 sites along the Nile from Aswan to Cairo ranged between 7.3 to 8.5 during winter and between 7.6to 8.3 during spring. While, during summer and autumn $\mathrm{pH}$ values were ranged between 7.7 to 8.6 and 7.7 to 9.0, respectively.

Table 9. Seasonally changes in $\mathrm{pH}$ in various treatment stages in Road El. Farag drinking water station.

\begin{tabular}{|c|c|c|c|c|c|c|c|c|}
\hline \multirow{3}{*}{ Locations } & \multicolumn{8}{|c|}{$\mathbf{p H}$} \\
\hline & \multicolumn{4}{|c|}{2016} & \multicolumn{4}{|c|}{2017} \\
\hline & Spring & Summer & Autumn & Winter & Spring & Summer & Autumn & Winter \\
\hline The source (River Nile) & 8.2 & 8.2 & 8.0 & 8.2 & 8.3 & 8.3 & 8.2 & 8.4 \\
\hline Clarification stage & 7.2 & 7.3 & 7.3 & 7.2 & 7.5 & 7.4 & 7.2 & 7.5 \\
\hline Filtration stage & 7.3 & 7.3 & 7.6 & 7.5 & 7.3 & 7.1 & 7.2 & 7.2 \\
\hline Final treatment & 7.35 & 7.3 & 7.0 & 7.5 & 7.3 & 7.4 & 7.1 & 7.1 \\
\hline \multicolumn{9}{|l|}{ Distribution regions } \\
\hline Road El-Farag & 7.1 & 7.4 & 7.0 & 7.2 & 7.1 & 7.3 & 7.5 & 7.1 \\
\hline El-Azhar & 7.2 & 7.4 & 7.4 & 7.2 & 7.5 & 7.6 & 7.2 & 7.1 \\
\hline El-Abasia & 7.4 & 7.3 & 7.3 & 7.5 & 7.4 & 7.3 & 7.5 & 7.5 \\
\hline
\end{tabular}

Also, Ezzat et al. (2012) showed that $\mathrm{pH}$ values water samples collected from the River Nile in summer and winter seasons were ranged from 7.45 to 7.9. Moreover, Abdel-Satar et al. (2017) reported that $\mathrm{pH}$ in the Nile River was generally on the alkaline side.

\section{Determination of the COD}

Chemical oxygen demand (COD) is a measure of the oxygen equivalent of the organic matter content of water that is susceptible to oxidation by a strong chemical oxidant. COD is a reliable parameter for guiding the extent of pollution in water (Pejman $\boldsymbol{e t}$ a1., 2009 and Garg et a1., 2010).

Data presented in Table (10) indicated that the lowest values were recorded in summer 2016 and winter 2017. Whereas, the highest values were recorded in summer 2017 for water samples that obtained directly from the River Nile during all examination seasons. Moreover, no COD values were recorded during the all examined distribution system. 
Table 10. Seasonally changes in COD in various treatment stages in Road El.Farag drinking water station.

\begin{tabular}{l|cccccccc}
\hline \multirow{2}{*}{\multicolumn{1}{c}{ Locations }} & \multicolumn{10}{c}{ COD (mg/l) } \\
\cline { 2 - 9 } & \multicolumn{9}{c}{ 2016 } & \multicolumn{1}{c}{ 2017 } \\
& Spring & Summer & Autumn & Winter & Spring & Summer & Autumn & Winter \\
\hline The source (River Nile) & 17.3 & 14.8 & 15.2 & 18.3 & 20.3 & 25.6 & 17.4 & 15.3 \\
Clarification stage & 3.50 & 2.60 & 3.10 & 2.60 & 4.20 & 5.20 & 3.60 & 2.50 \\
Filtration stage & 2.70 & 1.80 & 1.30 & 2.10 & 2.30 & 1.90 & 2.40 & 3.50 \\
Final treatment & 1.80 & 2.30 & 1.70 & 2.50 & 1.70 & 2.10 & 2.50 & 1.30 \\
Distribution regions & & & & & & & & \\
$\quad \quad$ Road El-Farag & 0.00 & 0.00 & 0.00 & 0.00 & 0.00 & 0.00 & 0.00 & 0.00 \\
$\quad$ El-Azhar & 0.00 & 0.00 & 0.00 & 0.00 & 0.00 & 0.00 & 0.00 & 0.00 \\
$\quad$ El-Abasia & 0.00 & 0.00 & 0.00 & 0.00 & 0.00 & 0.00 & 0.00 & 0.00 \\
\hline
\end{tabular}

Determination of the BOD

Biochemical oxygen demand (BOD) measurement involves determining the amount of dissolved oxygen required by bacteria to decompose organic matter in water through aerobic biochemical action, thus its determination constitutes a tool for organic pollution evaluation in water (Chapman, 1992).

Data presented in Table (11) showed that the highest BOD value $(15.2 \mathrm{mg} / \mathrm{l})$ was recorded in winter 2017 for water samples that obtained directly from the River Nile during all examination seasons. Moreover, no BOD values were recorded during the all examined distribution system. Ezzat et al. (2012) reported that $\mathrm{BOD}$ in the River Nile were ranged from 5.5-52.0 mg/l. While, Abdel-Satar et al. (2017) stated that BOD values were ranged between $(1.2-8.0$ $\mathrm{mg} / \mathrm{l}),(1.8-8.0 \mathrm{mg} / \mathrm{l}),(1.2-5.9 \mathrm{mg} / \mathrm{l})$ and $(1.8-6.5$ $\mathrm{mg} / \mathrm{l})$ during winter, spring, summer and autumn, respectively.

Table 11. Seasonally changes in BOD in various treatment stages in Road El.Farag drinking water station.

\begin{tabular}{|c|c|c|c|c|c|c|c|c|}
\hline \multirow{3}{*}{ Locations } & \multicolumn{8}{|c|}{ BOD (mg/l) } \\
\hline & \multicolumn{4}{|c|}{2016} & \multicolumn{4}{|c|}{2017} \\
\hline & Spring & Summer & Autumn & Winter & Spring & Summer & Autumn & Winter \\
\hline The source (River Nile) & 10.2 & 11.9 & 13.4 & 9.40 & 7.30 & 12.5 & 14.7 & 15.2 \\
\hline Clarification stage & 1.30 & 1.60 & 0.60 & 0.80 & 1.40 & 1.30 & 0.40 & 1.70 \\
\hline Filtration stage & 0.60 & 0.90 & 0.50 & 0.50 & 1.20 & 1.40 & 1.20 & 2.10 \\
\hline Final treatment & 0.70 & 0.30 & 0.60 & 0.10 & 0.30 & 0.60 & 0.70 & 0.50 \\
\hline \multicolumn{9}{|l|}{ Distribution regions } \\
\hline Road El-Farag & 0.00 & 0.00 & 0.00 & 0.00 & 0.00 & 0.00 & 0.00 & 0.00 \\
\hline El-Azhar & 0.00 & 0.00 & 0.00 & 0.00 & 0.00 & 0.00 & 0.00 & 0.00 \\
\hline El-Abasia & 0.00 & 0.00 & 0.00 & 0.00 & 0.00 & 0.00 & 0.00 & 0.00 \\
\hline
\end{tabular}

Additionally, El-Bouraie et al. (2011) indicated that BOD values were ranged between (1.0-130 mg/l), (2.0-110.0 mg/l), (1.0$80.0 \mathrm{mg} / \mathrm{l})$ and (1.0-75.0 mg/l) during winter, autumn, summer and spring, respectively.

\section{Conclusion}

Microbiological and physicochemical evaluation of drinking water in Road El-Farag station indicated that, the highest bacterial counts were recorded for water samples that obtained directly from the River Nile during all examination periods. Fecal streptococci, E. coli, Salmonella and Shigella were not detected in all distribution regions. The highest value of turbidity was observed during summer

Period followed by the spring in both seasons. The highest COD and BOD values were recorded in summer and winter 2017, respectively for water samples that obtained directly from the River Nile during all examination seasons.

\section{Acknowledgment}

The authors would like to express sincere appreciation to all staff members of Agric. Microbiology Dept., Faculty of Agriculture at Moshtohor, Benha University, for their kind cooperation.

\section{References}

Abdel-Satar, A.M. 2005 : Water quality assessment of River Nile from Idfo to Cairo. Egypt J. Aqua. Res., 31(2):200-223.

Abdel-Satar, A.M.; M. H. Ali and M. E. Goher 2017 : Indices of water quality and metal pollution of Nile River, Egypt. Egypt. Aqua. Res., 43:21-29.

Abo-State, M.A.; M. S. El-Gamal; A. El-Danasory and M. A. Mabrouk 2014 : Prevalence of Enterobacteriaceae and Streptococcus faecalis in surface water of Rosetta branch and its drains of River Nile, Egypt. World Appl. Sci:J., 31 (11):1873-1880.

Ahmed, N.A. 2012 Biochemical studies on pollution of the River Nile at different stations of Delta barrage (Egypt). Ph.D. In Chemistry, Fac. of Agric. Benha Univ., Egypt. 
Akan, A.O. and R. J. Houghtalen 2003 Urban hydrology, hydraulics and storm water quality. Wiley, Hoboken, New Jersey, U.S.A.

Ali, S.M.; E. M. Yones; A. M. Kenawy; T. B. Ibrahim and W. T. Abbas 2015 . Effect of ElSail drain wastewater on Nile tilapia (Oreochromis niloticus) from River Nile at Aswan, Egypt. J. Aqua. Res. Develop., 6(1):1-7.

Allen, M. J., S. C. Edberg and D. J. Reasoner 2004 Heterotrophic plate count bacteria, what is their significance in drinking water. International Journal of Food Microbiology 92: 265 - 274.

Annual Drinking Water Quality Report Village of Niles Utility Number IL031 2005 Annual Water Quality Report for the period of January 1 to December 31.

APHA: American public Health Association 1999 Standard methods for the examination of water and wastewater $20^{\text {th }}$ ed. APHA, Inc. New York.

APHA: American Public Health Association 2005 Standard methods for the examination of water and wastewater $\left(21^{\mathrm{st}}\right.$ ed.), Washington, D.C.

Besner, M. C.; M. Prevost and M. Regli 2011 Assessing the public health risk of microbial intrusion events in distribution systems: conceptual model, available data and challenges. Water Res. 45 (3), 961e979.

Chapman, D. 1992 Water quality assessments, $1^{\text {st }}$ ed. Chapman and Hall, London and New York.

Charmain, J. K.; K. S. Osborn; A. H. Rickard; G. D. Robson and P. S. Handley 2003 . Biofilms in water distribution systems. Handbook of Water and Wastewater Microbiology, Pages 757-775. United Utilities, Great Sankey, Warrington WA5 3LP; University of Manchester, Manchester M13 9PL, UK.

Dimian, M.; N. Donia; A. Wadi and F. Ibrahim 2014. El-Rahawy drain on the water quality of Rosetta branch of the River Nile, Egypt. Inter., J., Environ., Sci., and Engineering (IJESE), Vol. (5):15-23.

El-Bouraie, M.; M. Y. Mohamed and A. A. El Barbary 2011. Examining the concentration of organonitrogen pesticides in water at Nile Delta, Egypt. Iran. J. Energy Environ., 2 (4): 331-338.

El-Gammal, H.A. and H. S. El-Shazely 2008. Water quality management scenarios in Rosetta River Nile branch, Egypt. $12^{\text {th }}$ Int. Water Technol. Conf., Alex., Egypt, pp: 901-912.

El-Gohary, F.A. 1994. Comparative environmental risks in Cairo. Water pollution problems. In Comparing Environmental Health Risks in Cairo, Egypt, U.S.A.ID\& GoE, Vol. 2.

El-Taweel, G.E. and A. M. Shaban 2003. Microbiological monitoring and evaluation of River Nile water at Cairo segment and Ismailia Canal. Egypt. J. Microbiol., 38(2):169-182.

Encyclopedia Britannica 2017. Blue Nile River,
Africa. Archived from the original on $1^{\text {st }}$ August 2017.

Ezzat, S.M.; H. M. Mahdy; M. A. Abo-Astate; E. H. Abd El Shakour and M. A. El-Bahnasawy 2012. Water quality assessment of River Nile at Rosetta branch: Impact of drains discharge. Middle-East J. Sci. Res., 12:413-423.

Garg, R.K.; R. J. Rao; D. Uchchariya; G. Shukla and D. N. Saksena 2010. Seasonal variations in water quality and major threats to Ramsagar reservoir. India. Afri. J. Environ. Sci. Technol., 4:61-76.

Giannoulis, N.; V. Maipa; I. Konstantinou; T. Albanis and I. Dimoliatis 2005. Microbiological risk assessment of Agios Georgios source supplies in north western Greece based on faecal coliform determination and sanitary inspection survey. Chemosphere, 58:1269-1276.

Gordon, D.M. and F. FitzGibbon 1999. The distribution of enteric bacteria from Australian mammals: host and geographical effects. Microbiology, 145:2663-2671.

Mahmoud, S.A.; S. I. Tayel and A. M. Yacoub 2008. Histopathological changes in kidneys of the fish T. Zillii and C. Gariepinus under the effect of several pollutants along the River Nile. J. Egypt. German Soc. Zool., 56:219-246.

Manafi, M. 1999. New approaches for the fast detection of indicator, in particular enzyme detection methods (EDM). OECD Workshop Molecular Methods for Safe Drinking Water, pp: 1-16.

Osman, G.A.; M. M. Kamel; H. M. Hassan and A. Z. Al-Herrawy 2011. Microbial quality of Nile water and drinking water in some areas of Cairo, Egypt. Aust. Journal of Basic and Applied Sciences, 5(11): 1328-1334.

Pejman, A.H.; G. R. Nabi Bidhendi; A. R. Karbassi; N. Mehrdadi and M. Esmaeili 2009. Evaluation of spatial and seasonal variations in surface water quality using multivariate statistical techniques. Int. J. Environ. Sci. Tech., 6:467-476.

Sharma, S. and A. Bhattacharya 2017. Drinking water contamination and treatment techniques. Appl. Water Sci. 7:1043-1067.

Saad, S.M.; A. E. El-Deeb; S. I. Tayel and N. A. Ahmed 2011. Haematological and histopathological studies on Clarias gariepinus in relation to water quality along Rosetta branch, River Nile, Egypt. Egy. J. Exp. Biol. Zool., 7:223-233.

Sabae, S.Z. and S. A. Rabeh (2007): Evaluation of the microbial quality of the River Nile waters at Damietta branch, Egypt. Egy. J. Aqua. Res., 33:301- 311.

Saleh, M. A.; E. Ewane; J. Jones and B. L. Wilson 2001. Chemical evaluation of commercial bottled drinking water from Egypt. Journal of Food Composition and Analysis. 14: 127 - 152.

Shannon, M.A.; P. W. Bohn; M. Elimelech; J. G. 
Georgiadis; B. J. Marinas and M. Mayes 2008. Science and technology for water purification in the coming decades. Nature 452:301-310.

Silva, M. E. Z.; R.G. Santana; M. Guilhermetti; I. C. Filho; E. H. Endo; T. U. Nakamura; C. V. Nakamura and B. P. D. Filho 2008. Comparison of the bacteriological quality of tap water and bottled mineral water. Int. Hyg. Environ. Health. 211: $504-509$.
Stirling, H.P. 1985. Chemical and biological methods of water analysis for aquaculturalists. $1^{\text {st }}$ ed. Scotland, University of stirling.

WHO 1996. Guidelines for drinking-water quality. Recommendation vol $1,3^{\text {rd }}$ ed. World Health Organization, Geneva. 